\title{
Persian Gulf Snail Crude Venom (Conus textile): A Potential Source of Anti-Cancer Therapeutic Agents for Glioblastoma through Mitochondrial-Mediated Apoptosis
}

\author{
Ahmad Salimi', Niloofar Rahimitabar ${ }^{2}$, Amir Vazirizadeh ${ }^{3}$, Vahed Adhami', \\ Jalal Pourahmad ${ }^{2 *}$
}

\begin{abstract}
Background: Research on animal toxins have shown toxicity potential on cancerous cell and tissues in the cultures. Conotoxins obtained from marine cone snails show the highest toxicity potential, so that several human deaths have been attributed to this species of snail. These toxins have proven to be valuable agents to inhibit enzymes, channels and proteins, in the nervous systems of humans. Methods: We have studied the effects of Conus textile crude venom on U87MG human glioma cells and their mitochondria as main inducers of apoptosis and human embryonic kidney 293 cells (HEK293) as non-cancerous normal control cells. Cellular toxicity assessments including MTT (3-(4,5-dimethylthiazol2-yl)-2,5-diphenyltetrazolium bromide) assay and measurement of caspase-3 activation as well as mitochondrial toxicity assays including measurement of the activity of succinate dehydrogenase (SDH) enzyme, mitochondrial swelling, reactive oxygen species (ROS) production, collapse of mitochondrial membrane potential (MMP) and cytochrome c release were performed in U87MG human glioma cells and HEK293 cells (as non-cancerous normal cells). Results: The results illustrated the significant cytotoxic effect of Conus textile crude venom on U87MG human glioma cells, that inhibits $50 \%\left(\mathrm{IC}_{50}=10 \mu \mathrm{g} / \mathrm{mL}\right)$ of the cell growth after $12 \mathrm{~h}$ of exposure. Viability measurement showed which the Conus textile crude venom is selectively cytotoxic to U87MG human glioma cells, and induced activation of caspase-3 and induction of cell apoptosis via through mitochondrial signaling. Conus textile crude venom also selectively increased mitochondria swelling, ROS formation, cytochrome c release and MMP decrease in cancerous mitochondria but not normal mitochondria. Conclusion; Based on the obtained results from this investigation, it is concluded that the Conus textile crude venom contains promising natural compounds to fight U87MG human glioma cells through activation of apoptosis intrinsic pathways.
\end{abstract}

Keywords: Conus textile crude venom- conotoxins- mitochondria- apoptosis- glioblastoma

Asian Pac J Cancer Prev, 22, Anticancer Activity of Natural Compounds: HOW's on Methods and Reports Suppl, 49-57

\section{Introduction}

Animal toxins are made of types of peptides and proteins well-tuned during millions of years of evolution (Escoubas and King, 2009). These venoms target various enzymes, receptors, and ion channels with great potency and sometimes good selectivity, hence, it is led to more attention to more research their physiological and pharmacological attributes (Escoubas and King, 2009). These venoms are made by poisonous animals from both marine animals and terrestrial animals, are injected into the body of victim for defense or hunt by animal wounding apparatus (Harvey, 2014). For thousand years in many parts of the world, some poisonous animals have been applied to remedy illnesses (Harvey, 2014). It has been reported many important effects of animal toxins after functionality studies. The high potency and selectivity make these toxins as shining drug candidates and pharmacological tools (Prashanth et al., 2017). Although animal toxins display higher potency and selectivity compared to drugs for pharmacological application, they still face many challenges, such as the poor oral bioavailability, lack of membrane permeability and short circulating half-life (Chen et al., 2018). Marine cone snails such as Conus textile prepare one of the highest toxin varieties between toxic animals. These marine cones are venomous and predatory species of sea snail (Favreau and Stöcklin, 2009). Several human deaths have been attributed to this species of snail (Kohn, 2016). The toxins of cone snails usually named conotoxins or conopeptides,

${ }^{1}$ Department of Pharmacology and Toxicology, School of Pharmacy, Ardabil University of Medical Sciences, Ardabil, Iran. ${ }^{2}$ Department of Pharmacology and Toxicology, Faculty of Pharmacy, Shahid Beheshti University of Medical Sciences, Tehran, Iran. ${ }^{3}$ Persian gulf research institute, Marine biology and Fishery sciences Department, Persian gulf University, Iran. *For Correspondence: j.pourahmadjaktaji@utoronto 
have always been one of the main sources for novel therapeutic agent exploration (Lewis, 2009). These toxins have demonstrated to be considerable potential drugs and pharmacological agents due to their great affinity and specificity to receptors, transporters and ionic channels, in the central nervous systems (CNS) and peripheral nervous systems (PNS) of humans and target prey (Mir et al., 2016). Therefore, the application of them for brain cancers can probably be helpful.

Some reasons are involved in cancer disease, which resulting in abnormal and uncontrolled proliferation of cells in the body. Cancer disease directly affects the quality of life and even leads to death. Cancer disease displays the illness of the millenary, a main topic in public health (Feuerstein and Nekhlyudov, 2007). For treatment of cancer, chemotherapy is usually used together with surgical procedures and/or radiation therapy (Sawyers, 2004). The lacking of target specificity in chemotherapy leads to more risks of undesired side effects (Sawyers, 2004). One of this cancer is glioma. Glioma is the most widespread and most aggressive early neoplasia brain cancer in matures (Davis, 2016). The most aggressive form of glioma with, name glioblastoma (GBM) presents around $50 \%$ of patients (Davis, 2016). The above-mentioned therapies, have not led to major amelioration in the survivorship results of patients with glioma (Davis, 2016). Recent studies showed that antitumor drug development based on animal toxins has become one of the novel action plans to treatment of cancer diseases (Ma et al., 2017). Toxins obtained from venomous animals show the activity of potent cytotoxic to tumor cells via alteration of the cell cycle, modulation of the impairment of cancer proliferation, inhibition of enzymatic activities and apoptosis response pathway (Gomes et al., 2010). There are two ways for induction of apoptosis including intrinsic and extrinsic pathways. In the intrinsic or mitochondrial pathway the cell senses cell stress and kills itself while in the intrinsic pathway or death receptor mediated the cell receives signals from other cells and kills itself (Burz et al., 2009). Therefore, triggering of apoptosis through mitochondrial pathway can be useful for more potent and selective therapy. Moreover, in glioma cells, mitochondrial dysfunction in metabolic capacity was proven with detection of mutations in at nucleotides coding for arginine in enzyme isocitrate dehydrogenase (IDH). The gene encoding the cytosolic form of IDH1 is the one of the main mutations in the glioblastomas. Mutations at R172 in IDH2 gene is associated with loss of enzymatic activity (Zhu et al., 2011). These mutations lead to mitochondrial damages and finally mitochondrial dysfunction and loss of energy production in the gliomas (Dang et al., 2010). In this study, we searched the selective cytotoxicity of Conus textile crude venom on U87MG human glioma cells and their mitochondria and compared the findings with those of HEK293 cells as non-cancerous normal control cells.

\section{Materials and Methods}

Chemicals and reagents $\mathrm{N}$-(2-hydroxyethyl) piperazine-N '-(2-ethanesulfonic acid) (HEPES), 2 ',7 '-dichlorofuorescin diacetate (DCFH-DA), Coomassie
Brilliant Blue, Ethylene glycol-bis( $\beta$-aminoethyl ether (EGTA), Trypan blue, Bovine serum albumin (BSA), 2,2',2",2"'-(Ethane-1,2-diyldinitrilo) tetra acetic acid (EDTA), Rhodamine123, D-mannitol, Sucrose, Dimethyl sulfoxide (DMSO), 2-Amino-2-hydroxymethyl-propane1,3-diol (TRIS), 4,5-dimethylthiazol-2-yl)-2,5-diphenyl tetrazolium bromide (MTT), 3-morpholinopropane-1sulfonic acid (MOPS), Magnesium chloride, Sodium succinate, Mono potassium phosphate, Potassium chloride and Rotenone were procured from Sigma (St. Louis, MO USA). Caspase-3 Assay Kit (ab39401) and Cytochrome C Release Assay Kit (ab65311) from abcam (Cambridge. UK).

\section{Cell Line}

Human embryonic kidney 293 cells (HEK 293) and U87MG human glioma cell line were procured from the Pasteur Institute of Iran (Tehran. Iran). U87MG and HEK 293 cells were maintained in Dulbecco's modified eagle's medium (DMEM) containing $2 \mathrm{mM}$ L-glutamine, $100 \mathrm{U} /$ $\mathrm{ml}$ penicillin, $100 \mathrm{U} / \mathrm{ml}$ streptomycin and $10 \% \mathrm{FBS}$ at $37^{\circ} \mathrm{C}$ in a humidified atmosphere of $5 \% \mathrm{CO}_{2}$.

\section{Animal and Venom Extraction}

The Conus textile samples were collected from Larak Island in Persian Gulf, in the south of Iran. alive snails were maintained and frozen at $-70^{\circ} \mathrm{C}$. On a petri dish on ice, snails were anatomized and the venom ducts were isolated and the venom extraction was carried out as previously published Tabaraki et al. Briefly, the venom ducts were homogenized in $200 \mu$ l of cold sterile water and centrifugated at $16,000 \times \mathrm{rpm}$ for $5 \mathrm{~min}$. This mixture was centrifuged again at $10,000 \times \mathrm{g}$ for $20 \mathrm{~min}$ at $4^{\circ} \mathrm{C}$. At the end, the obtained supernatant was lyophilized by a freeze dryer and maintained at $-20^{\circ} \mathrm{C}$ (Tayo et al., 2010; Tabaraki et al., 2014). Crude venom was dissolved in normal saline and normal saline was used as control group.

\section{Mitochondria Isolation and Purification}

U87MG human glioma cells and human embryonic kidney 293 cells $\left(6 \times 10^{6}\right)$ at exponentially growing situation were collected, eluted twice in cold PBS at $4^{\circ} \mathrm{C}$ on ice, and mitochondria were separated using differential centrifugation as described previously. Using a high-salt wash buffer containing $1 \mathrm{mM}$ EDTA, $250 \mathrm{mM}$ sucrose, 10 $\mathrm{mM}$ Tris- $\mathrm{HCl}, 4 \mathrm{M} \mathrm{NaCl}$ with $\mathrm{pH} 7.4$ the mitochondrial pellet was stripped of other contaminating organelles. Following, mitochondria were isolated again at 8,000 $\mathrm{g}$ at $4^{\circ} \mathrm{C}$ for 15 minutes by centrifugation (Faizi et al., 2014). The protein content in mitochondria was determined using the Bradford method was determined (Bradford, 1976). Protein concentration in the suspension was $1,000 \mu \mathrm{g} / \mathrm{mL}$. The purity and integrity of mitochondria were tested by using lactate dehydrogenase and SDH assays.

\section{Cell Viability Assessment}

U87MG human glioma cells and human embryonic kidney 293 cells (104 per well in 96-well plate) were treated to different concentrations of crude venom $(0$, $1 \mathrm{ng} / \mathrm{ml}, 10 \mathrm{ng} / \mathrm{ml}, 100 \mathrm{ng} / \mathrm{ml}, 1 \mu \mathrm{g} / \mathrm{ml}, 10 \mu \mathrm{g} / \mathrm{ml}$, and $100 \mu \mathrm{g} / \mathrm{ml})$. Cell viability at 12 hours was determined 
by MTT $(0.5 \mathrm{mg} / \mathrm{ml})$ assay for 4 hours. Then, by adding $100 \mu \mathrm{l}$ DMSO, the optical density of the solution at 570 $\mathrm{nm}$ wavelength was detected using an enzyme-linked immunosorbent assay (ELISA) reader (Tecan, Rainbow hermo, Austria) (Borhani et al., 2017).

\section{Caspase Activity Determination}

Caspase-3 Assay Kit (ab39401) from abcam (Cambridge. UK) was used to assay the caspase 3 activation in the lysates of the cells. The cells were exposed with IC50 of crude venom for $12 \mathrm{~h}$, and then in a buffer mixture containing $2 \mathrm{mM}$ DTT, $1 \mathrm{mM}$ EDTA, $50 \mathrm{mM}$ Tris- $\mathrm{HCl}$ (pH 7.4), $10 \mathrm{mM}$ EGTA, and $10 \mathrm{mM}$ digitonin were lysed. Ac-DEVD-pNA was used and for incubating of the cell lysate at $37^{\circ} \mathrm{C}$ for $1 \mathrm{~h}$ as casepase- 3 substrate. Caspase- 3 activity and absorbance were measured using an ELISA reader (Tecan, Rainbow hermo, Austria) at 405 $\mathrm{nm}$. Three experiments were independently performed for caspase-3 activity determination (Lee et al., 2018).

\section{Mitochondrial SDH Activity Assay}

The activity of complex II or SDH activity was detected by measuring the reduction of the tetrazolium dye MTT. Shortly, $100 \mu \mathrm{L}$ (containing $100 \mu \mathrm{g}$ ) of mitochondria was exposed with various concentrations of crude venom $(0,1 \mathrm{ng} / \mathrm{ml}, 10 \mathrm{ng} / \mathrm{ml}, 100 \mathrm{ng} / \mathrm{ml}, 1 \mu \mathrm{g} / \mathrm{ml}, 10 \mu \mathrm{g} / \mathrm{ml}$, and $100 \mu \mathrm{g} / \mathrm{ml}$ ) at $37^{\circ} \mathrm{C}$ for $1 \mathrm{~h}$; afterward, $25 \mu \mathrm{L}$ of dye MTT $(0.4 \%)$ was added to the medium and incubated for 30 $\min$ at $37^{\circ} \mathrm{C}$. Then the produced insoluble formazan was solved in $100 \mu \mathrm{L}$ dimethyl sulfoxide (DMSO) and the absorbance at $570 \mathrm{~nm}$ was measured with an ELISA reader (Tecan, Rainbow hermo, Austria). Three independent experiments were run for SDH activity determination (Faizi et al., 2014).

\section{Determination of Mitochondrial Swelling}

$100 \mu \mathrm{g}$ protein per well of mitochondria were seeded in 96 -well plates at $37^{\circ} \mathrm{C}$ in swelling buffer containing $10 \mathrm{mM} \mathrm{NaCl}, 140 \mathrm{mM} \mathrm{KCl}, 0.5 \mathrm{mM} \mathrm{KH} \mathrm{PO}_{4}, 2 \mathrm{mM}$ $\mathrm{MgCl} 2,0.5 \mathrm{mM}$ EGTA, $20 \mathrm{mM}$ HEPES, supplemented with $10 \mathrm{mM}$ succinate and $1,000 \mu \mathrm{g} / \mathrm{mL}$ rotenone with $\mathrm{pH}$ 7.2. After $10 \mathrm{~min}$ of pre-incubation of mitochondria with different concentrations of crude venom including $1 / 4$ $\mathrm{IC}_{0}, 1 / 2 \mathrm{IC}_{50}$ and $\mathrm{IC}_{50}(2.5,5$ and $10 \mu \mathrm{g} / \mathrm{ml})$ mitochondrial swelling were monitored each $15 \mathrm{~min}$ at $540 \mathrm{~nm}$ by an ELISA reader (Tecan, Rainbow hermo, Austria). Three independent experiments were run for mitochondrial swelling determination (Faizi et al., 2014).

\section{Determination of Mitochondrial ROS Generation}

The ROS generation in fresh isolated mitochondria was detected using the fluorescent reagent DCFH-DA. Briefly, isolated mitochondria were suspended in respiration buffer containing $10 \mathrm{mM}$ Tris, $0.1 \mathrm{mM} \mathrm{KH} 2 \mathrm{PO} 4,20 \mathrm{mM}$ Mops, $5 \mathrm{mM}$ sodium succinate, $0.5 \mathrm{mM} \mathrm{MgCl} 2,0.32 \mathrm{mM}$ sucrose and $50 \mu \mathrm{M}$ EGTA with $\mathrm{pH} 7.4$ and supplemented with $10 \mu \mathrm{M}$ DCFH-DA. After $10 \mathrm{~min}$ of pre-incubation of mitochondria with various concentrations of crude venom including $1 / 4 \mathrm{IC}_{50}, 1 / 2 \mathrm{IC}_{50}$ and $\mathrm{IC}_{50}(2.5,5$ and $10 \mu \mathrm{g} /$ $\mathrm{ml}$ ), the fluorescence intensity of DCF was monitored at $37^{\circ} \mathrm{C}$ for an hour using Shimadzu RF-5000U fluorescence spectrophotometer at an excitation wavelength of 488 $\mathrm{nm}$ and emission wavelength of 527. Three independent experiments were run for mitochondrial ROS formation determination (Salimi et al., 2016; Arab-Nozari et al., 2020).

\section{Determination of MMP Collapse}

Rhodamine 123 as a chemical compound and cationic fluorescent dye, has been used for the measurement of mitochondrial membrane potential (MMP) collapse. The isolated mitochondria $(1,000 \mu \mathrm{g}$ protein/ml) were suspended in MMP assay buffer containing $10 \mathrm{mM}$ $\mathrm{KCl}, 5 \mathrm{mM} \mathrm{KH} \mathrm{KO}_{2}, 5 \mathrm{mM}$ sodium succinate, 220 $\mathrm{mM}$ sucrose, $2 \mathrm{mM} \mathrm{MgCl}$, $68 \mathrm{mM}$ D-mannitol, $50 \mu \mathrm{M}$ EGTA, $10 \mathrm{mM}$ HEPES and $2 \mu \mathrm{M}$ rotenone with $\mathrm{pH} 7.4$ and supplemented with $10 \mu \mathrm{M}$ of rhodamine 123 . After $10 \mathrm{~min}$ of pre-incubation of mitochondria with various concentrations of crude venom including $1 / 4$ IC50, $1 / 2$ $\mathrm{IC}_{50}$ and $\mathrm{IC}_{50}(2.5,5$ and $10 \mu \mathrm{g} / \mathrm{ml})$, the fluorescence intensity was monitored at $37^{\circ} \mathrm{C}$ for an hour by using Shimadzu RF-5000U fluorescence spectrophotometer at the excitation and emission wavelength of $490 \mathrm{~nm}$ and $535 \mathrm{~nm}$, respectively (Faizi et al., 2014).

\section{Determination of Cytochrome C Release}

Fresh functional mitochondria were placed in $1.5-\mathrm{mL}$ tubes within buffer assay containing $2 \mathrm{mM} \mathrm{MgCl}, 10 \mathrm{mM}$ $\mathrm{NaCl}, 140 \mathrm{mM} \mathrm{KCl}, 0.5 \mathrm{mM} \mathrm{KH} \mathrm{PO}_{4}, 20 \mathrm{mM}$ HEPES and $0.5 \mathrm{mM}$ EGTA with $\mathrm{pH}$ 7.4. After an hour of exposure with different concentrations of crude venom including $1 / 4 \mathrm{IC}_{50}, 1 / 2 \mathrm{IC}_{50}$ and $\mathrm{IC}_{50}(2.5,5$ and $10 \mu \mathrm{g} / \mathrm{ml})$, the treated mitochondria were centrifuged at $10,000 \times \mathrm{g}$ for $10 \mathrm{~min}$. The concentration of cytochrome $\mathrm{c}$ was determined at supernatant contained the cytochrome $\mathrm{c}$ released from the mitochondria (cytosolic fraction) and the pellet consisted of the mitochondrial fraction using the Cytochrome $\mathrm{c}$ Release Assay Kit (ab65311) from abcam (Cambridge. UK) in accordance with the manufacturer's instructions (Salimi et al., 2016; Mirshafa et al., 2020).

\section{Data Analysis}

Graph Pad Prism (version 5, Graph Pad Software Inc., La Jolla, CA, USA) was used for data analysis. Statistical significance was determined using the one-way ANOVA test, followed by the post-hoc Tukey posttest and two-way ANOVA followed by the posttest Bonferonie. Statistical significance was set at $p<0.05$. Results are presented as mean $\pm \mathrm{SD}$. Assays were performed in triplicate and the mean was used for statistical analysis.

\section{Results}

\section{Cell Viability Assay}

For determination of cytotoxic effect of Conus textile crude venom on U87MG human glioma cells and human embryonic kidney 293 cells we used MTT assay. Our data indicated that crude venom of Conus textile was more cytotoxic on U87MG human glioma cells compared to human embryonic kidney 293 cells. As shown in Figure $1 \mathrm{~A}$, crude venom at concentrations of up to $10 \mathrm{ng} / \mathrm{ml}$, significantly $(\mathrm{p}<0.001)$ caused cytotoxicity, while no 
A

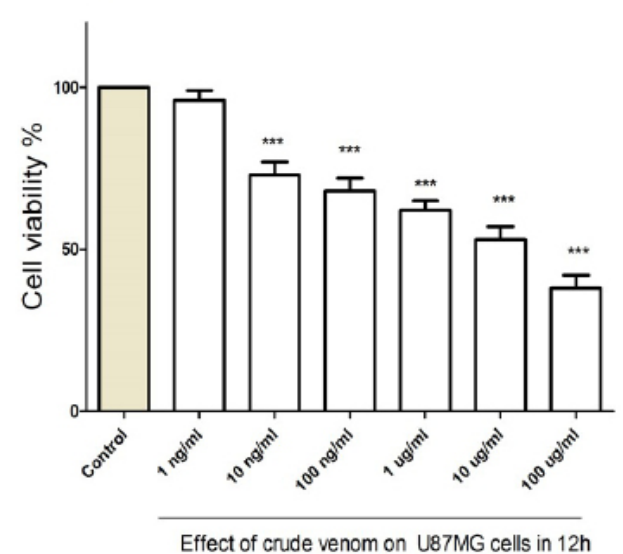

B

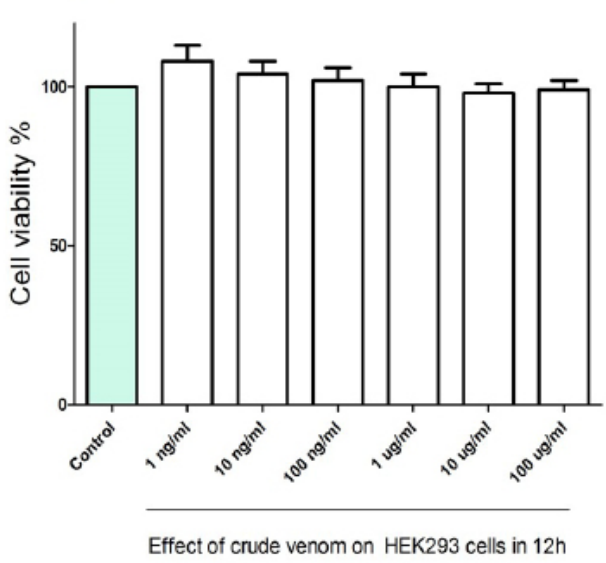

Figure 1. Effect of Crude Venom of Conus Textile on Viability of U87MG Human Glioma Cells (A) and human embryonic kidney 293 cells (B). Cells were treated with the different concentrations of crude venom $(0,1 \mathrm{ng} / \mathrm{ml}, 10$ $\mathrm{ng} / \mathrm{ml}, 100 \mathrm{ng} / \mathrm{ml}, 1 \mu \mathrm{g} / \mathrm{ml}, 10 \mu \mathrm{g} / \mathrm{ml}$, and $100 \mu \mathrm{g} / \mathrm{ml}$ ) and cell viability was measured by MTT assay at $12 \mathrm{~h}$. Values were expressed as mean $\pm \mathrm{SD}$ of three separate determinations. (*** $<0.001$ vs. untreated control with crude venom).

cytotoxicity was showed at these concentrations on human embryonic kidney 293 cells (Figure 1 B).

\section{Caspase 3 assay}

Apoptotic signaling leads to caspase-3 activation through both intrinsic (mitochondrial) and extrinsic (death ligand) pathways. As illustrated in Figure 2, crude venom $(5$ and $10 \mu \mathrm{g} / \mathrm{ml})$ significantly increased the activity of caspase- 3 as an executioner caspase of apoptosis in U87MG cells. Increased caspase-3 activity in the used concentration in U87MG human glioma cells was not shown in human embryonic kidney 293 cells. To understand the upstream mechanism involved in crude venom-induced caspase- 3 activation we tested the pretreating effect of Z-DEVD a caspase 3 inhibitor and Z-IETD a caspase 8 inhibitor. Our data showed that Z-IETD as a caspase 8 inhibitor has no effect on crude venom-induced caspase- 3 activation, suggesting that crude venom activates a mitochondria-mediated intrinsic pathway apoptosis in U87MG human glioma cells but no human embryonic kidney 293 cells.

\section{SDH Activity}

To Evaluate the effect of crude venom on mitochondria isolated from both U87MG human glioma cells and human embryonic kidney 293 cells, we tested the inhibitory effects of the crude venom on complex II activity using the MTT assay. Crude venom of Conus textile up to $2.5 \mu \mathrm{g} /$ $\mathrm{ml}$ strongly inhibited complex II activity only in isolated mitochondria obtained from U87MG human glioma cells

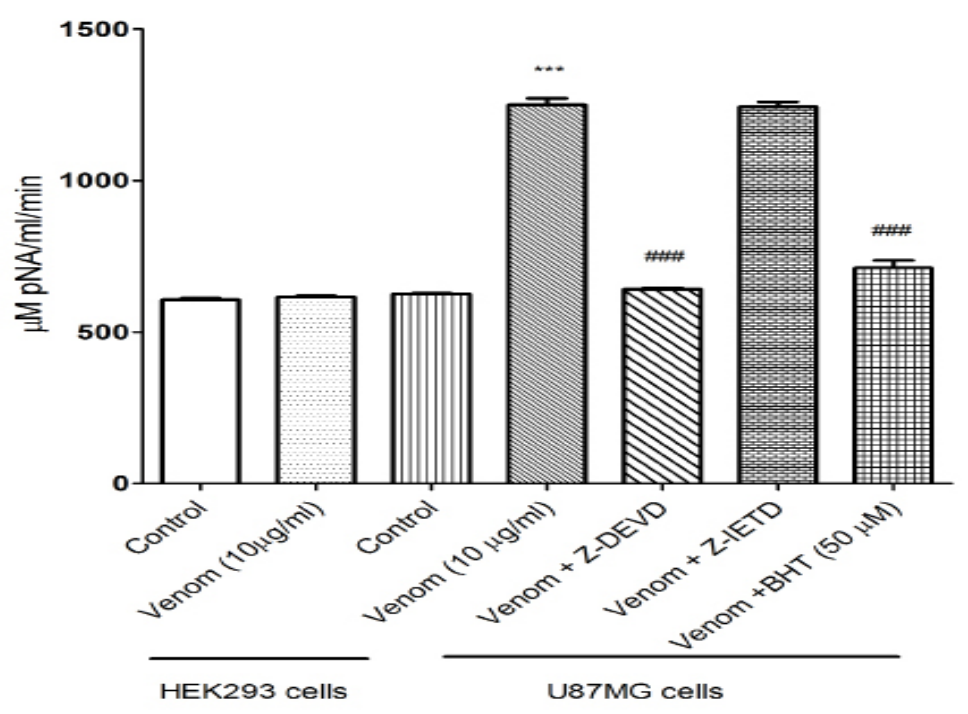

Figure 2. Effect of Crude Venom on Caspase-3 Activation in U87MG Human Glioma Cells (A) and human embryonic kidney 293 cells (B). Cells $\left(10^{6}\right.$ cells $\left./ \mathrm{mL}\right)$ were treated with $2.5,5$ and $10 \mu \mathrm{g} / \mathrm{ml}$ crude venom at $12 \mathrm{~h}$. Caspase-3 activity was determined by Sigma-Aldrich kit. The kit determines produced pNA that is released from the interaction of caspase-3 and AC-DEVD-pNA (peptide substrate). crude venom significantly increased the activity of caspae-3 in U87MG human glioma cells but not in human embryonic kidney 293 cells. Z-IETD a caspase 8 inhibitor not affected on caspase 3 activation. Values are expressed as mean \pm SD of three separate experiments $(n=5)$. ***: Significant difference in comparison with cancerous control $(\mathrm{p}<0.001)$ and \#\#\# Significant difference in comparison with $10 \mu \mathrm{g} /$ $\mathrm{ml}$ crude venom $(\mathrm{p}<0.001)$. 
A

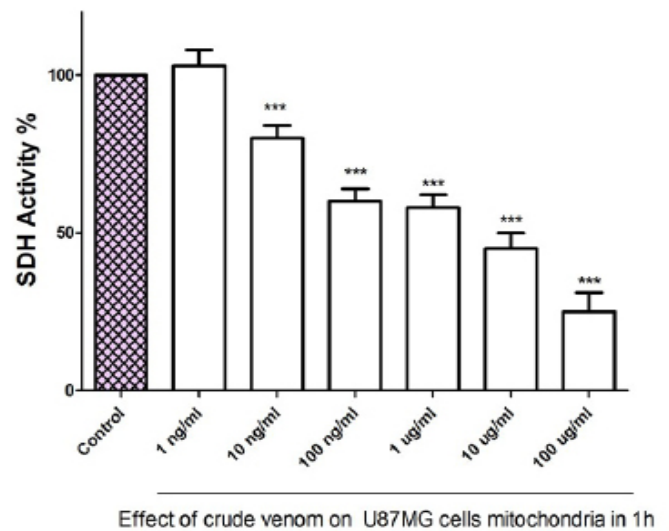

B

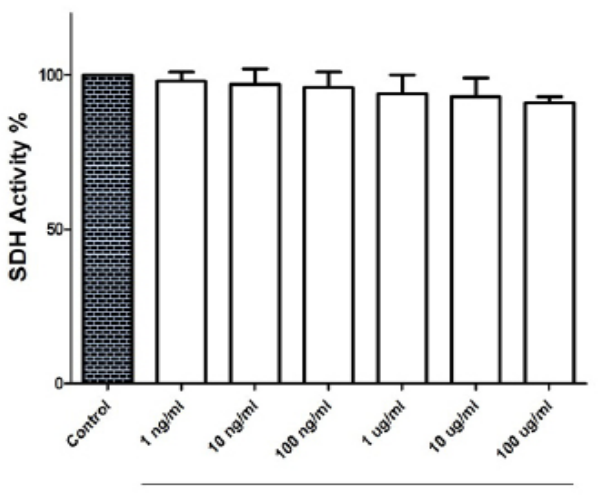

Effect of crude venom on HEK293 cells mitochonsria in $1 \mathrm{~h}$

Figure 3. Effect of Crude Venom on Succinate Dehydrogenase Activity in U87MG Human Glioma Cells (A) and human embryonic kidney 293 cells mitochondria (B). This figure demonstrates the effect of the crude venom on succinate dehydrogenase activity in both group mitochondria. Mitochondrial succinate dehydrogenase activity was measured by MTT assay within $1 \mathrm{~h}$ after crude venom exposure. Values were expressed as mean $\pm \mathrm{SD}$ of three separate determinations. $(* * * p<0.001$ vs. untreated control with crude venom).

but not in mitochondria obtained from human embryonic kidney 293 cells. The $\left(\mathrm{IC}_{50}\right)$ was defined as concentration of venom that decreased the SDH activity down to $50 \%$ in mitochondria U87MG human glioma cells following $60 \mathrm{~min}$ of exposure. $\mathrm{IC}_{50}$ determination was based on a regression plot of three different concentrations (data and curves not shown) (Figure $3 \mathrm{~A}-\mathrm{B}$ ).

\section{Mitochondrial swelling}

Monitoring the decrease of absorbance at $540 \mathrm{~nm}$ (A540) for induction of mitochondrial swelling by crude venom on mitochondria isolated from both U87MG human glioma cells and human embryonic kidney 293 cells were performed. Crude venom of Conus textile $(2.5,5$, and $10 \mu \mathrm{g} / \mathrm{ml})$ caused an extensive mitochondrial swelling in mitochondria isolated from U87MG human glioma cells (Figure 4A). Crude venom addition to mitochondria obtained from human embryonic kidney 293 cells $(2.5,5$, and $10 \mu \mathrm{g} / \mathrm{ml})$ not resulted in mitochondrial swelling (Figure 4B).

\section{ROS Generation}

ROS has a key role in cell survival and death. We tested the effect of crude venom of Conus textile $(2.5,5$, and $10 \mu \mathrm{g} / \mathrm{ml}$ ) on cancerous mitochondria obtained from U87MG human glioma cells for ROS formation using DCFH-DA dye. As shown in Figure 5A, treatment with crude venom at $2.5,5$, and $10 \mu \mathrm{g} / \mathrm{ml}$ after 30 minutes, significantly increased ROS generation $(\mathrm{p}<0.05)$ in cancerous mitochondria. These results indicated that crude venom caused ROS formation might underlie its effect on promoting U87MG human glioma cells apoptosis. However as shown in Figure 5B, treatment with crude venom at $52.5,5$, and $10 \mu \mathrm{g} / \mathrm{ml}$ did not induce
A

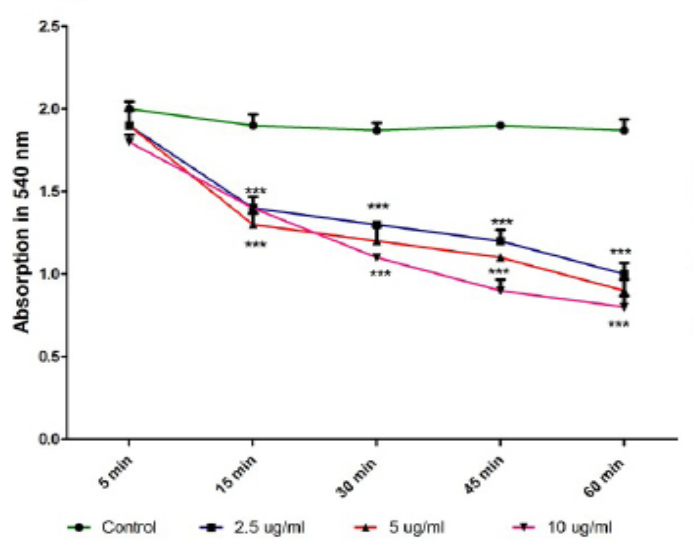

Effect of venom on U87MG cells mitochondria in $1 \mathrm{~h}$

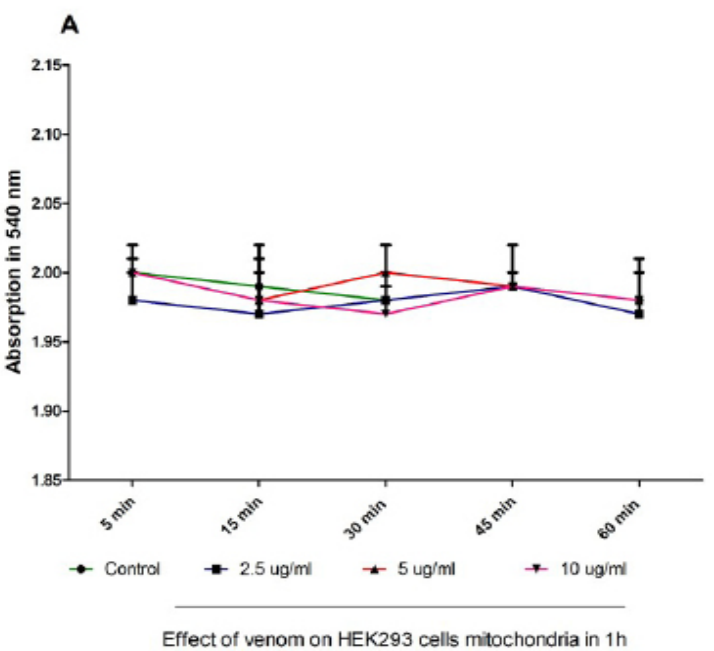

Figure 4. Effect of Crude Venom on Mitochondrial Swelling in U87MG Human Glioma Cells (A) and human embryonic kidney 293 cells mitochondria (B). Crude venom at different concentrations $(2.5,5$ and $10 \mu \mathrm{g} / \mathrm{ml}) \mathrm{induced}$ mitochondrial swelling in U87MG human glioma cells mitochondria but not (A) and human embryonic kidney 293 cells mitochondria. Mitochondrial swelling was monitored by following $540 \mathrm{~nm}$ absorbance decrease. Values were expressed as mean $\pm \mathrm{SD}$ of three separate determinations. (***p<0.001 vs. untreated control with crude venom). 
A

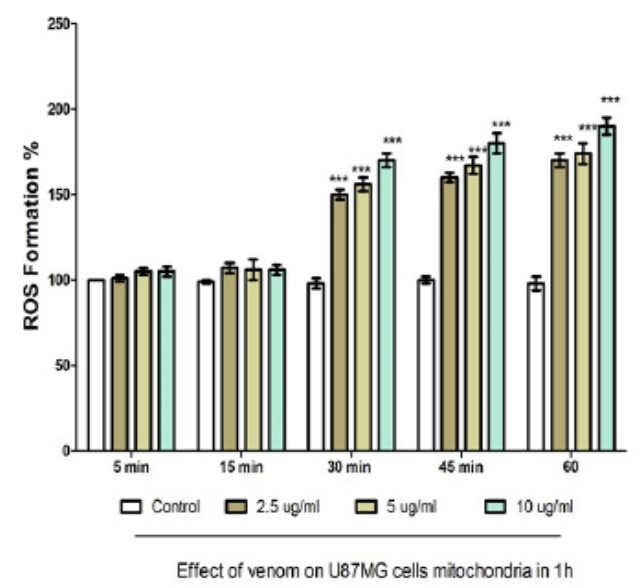

B

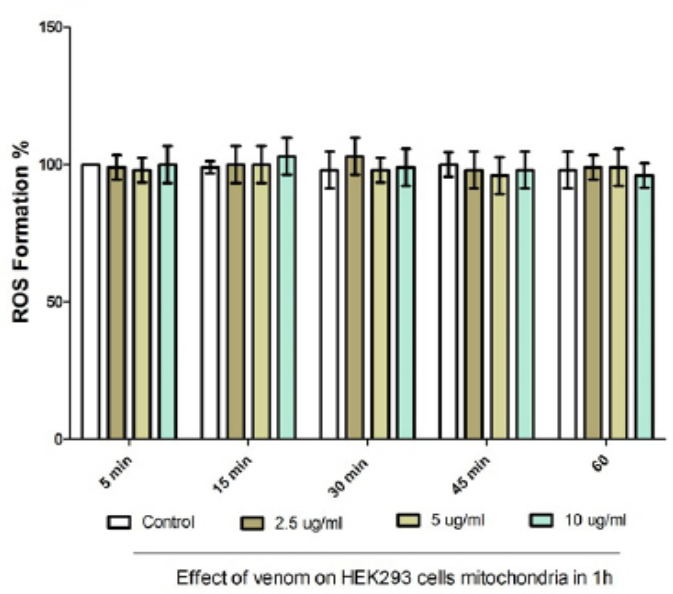

Figure 5. Effect of Crude Venom on ROS Formation in U87MG Human Glioma Cells (A) and human embryonic kidney 293 cells mitochondria (B). Freshly isolated mitochondria were incubated from both groups with the different concentrations of crude venom $(2.5,5$ and $10 \mu \mathrm{g} / \mathrm{ml})$ for 1 hour. ROS was measured by DCFH-DA staining with spectrofluorescence method. The ROS formation percentage was significantly increased $(\mathrm{p}<0.001)$ by crude venom in comparison to untreated control in U87MG human glioma cells mitochondria. human embryonic kidney 293 cells mitochondria the changes of the ROS formation percentage were not significant. Values were expressed as mean \pm SD of three separate determinations. ( $* * * p<0.001$ vs. untreated control with crude venom).

ROS generation in mitochondria obtained from human embryonic kidney 293 cells.

\section{MMP Assay}

To investigate for the discovery of mechanisms involved in cell death, we searched the effects of crude venom of Conus textile $(2.5,5$, and $10 \mu \mathrm{g} / \mathrm{ml})$ on MMP collapse $(\Delta \Psi \mathrm{m})$ in isolated mitochondria from both U87MG human glioma cells and human embryonic kidney 293 cells. Exposure with various concentrations of crude venom $(2.5,5$, and $10 \mu \mathrm{g} / \mathrm{ml}$ for $1 \mathrm{~h})$ caused remarkable decrease in $\Delta \Psi \mathrm{m}$ only in cancerous mitochondria obtained from U87MG human glioma cells only after 15 minutes of exposure (Figure 6B). Treatment with crude venom (2.5, 5 , and $10 \mu \mathrm{g} / \mathrm{ml}$ for $1 \mathrm{~h}$ ) did not induce MMP collapse $(\triangle \Psi \mathrm{m})$ in normal mitochondria obtained from human embryonic kidney 293 cells (Figure 6B).

\section{Measurement of Cytochrome C Release}

Presented data at Figure $4 \mathrm{~A}$ and $6 \mathrm{~A}$ shows that the crude venom of Conus textile at $2.5,5$, and $10 \mu \mathrm{g} / \mathrm{ml}$ for $1 \mathrm{~h}$ remarkably induced collapse of the mitochondrial membrane potential and mitochondrial swelling in isolated mitochondria from both U87MG human glioma cells. Two above events could cause mitochondrial permeability transition ore (mPTP or MPTP) and release of cytochrome

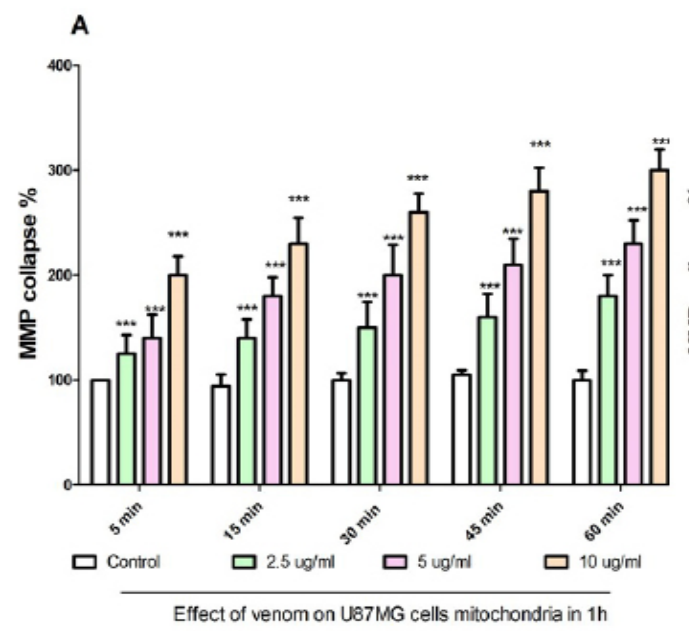

B

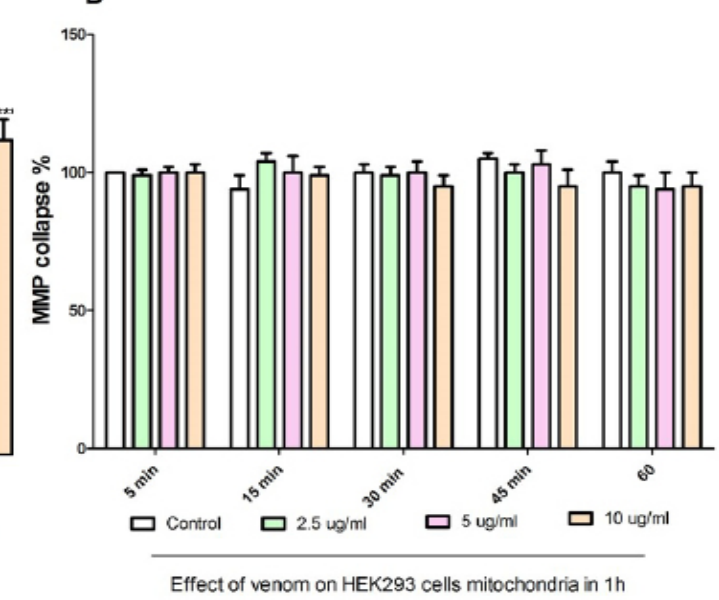

Figure 6. Effect of Crude Venom on $\Delta \Psi \mathrm{m}$ in U87MG Human Glioma Cells (A) and human embryonic kidney 293 cells mitochondria (B). Freshly isolated mitochondria from both group cells were treated with the different concentrations of crude venom $(2.5,5$ and $10 \mu \mathrm{g} / \mathrm{ml})$ for 1 hour. $\Delta \Psi \mathrm{m}$ was measured spectrophotometrically by rhodamine 123 staining. The presented data revealed that the crude venom induced a decrease in $\triangle \Psi \mathrm{m}$ only in U87MG human glioma cells mitochondria but not in human embryonic kidney 293 cells mitochondria. Values were expressed as mean \pm SD of three separate determinations. (***p<0.001 vs. untreated control with crude venom). 

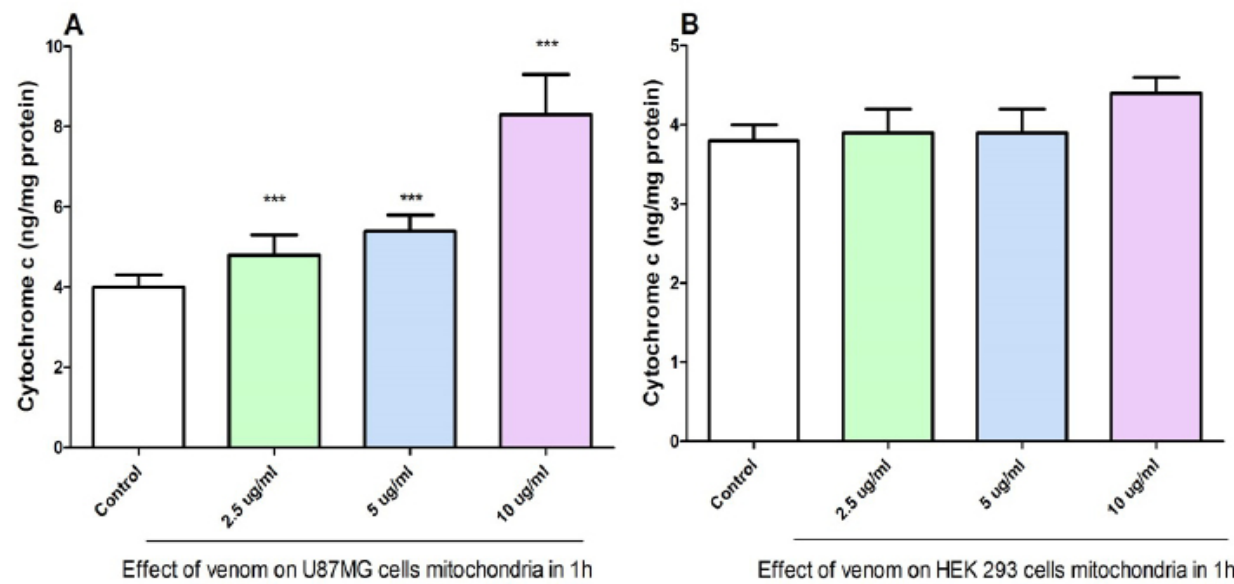

Figure 7. Effect of Crude Venom on the Cytochrome c Release in in U87MG Human Glioma Cells (A) and human embryonic kidney 293 cells mitochondria (B). As shown in this figure, pretreatment with crude venom in U87MG human glioma cells mitochondria significantly induced cytochrome c release but not in human embryonic kidney 293 cells mitochondria. The amount of expelled cytochrome c from mitochondrial fraction into the suspension buffer was determined using human Cytochrome c ELISA kit. Values were expressed as mean \pm SD of three separate determinations. $(* * * \mathrm{p}<0.001$ vs. untreated control with crude venom).

c into the cytosolic fraction from mitochondria. crude venom of Conus textile at $2.5,5$, and $10 \mu \mathrm{g} / \mathrm{ml}$ caused significant $(\mathrm{p}<0.05)$ release of cytochrome $\mathrm{c}$ in glioma mitochondria but not in mitochondria obtained from human embryonic kidney 293 cells.

\section{Discussion}

The Global Cancer Statistics in 2015 has been reported which, there are nearly 32.6 million patients with different cancers around the world (Torre et al., 2015). Without a doubt cancer is one of the main primary causes of death in the world (Bray et al., 2018). Successful development of targeted therapy in the last decades, has significantly increased the survival rate of about 5-years for all types of cancers (Hashim et al., 2016). Therefore, there is an urgency to unendingly expand some new active compounds which could act in a combination with the available drugs or alone to fight against the complex and severe cancer diseases. Animal venoms are one of the stimulating expansions in the field of anti-tumor investigation (Ma et al., 2017). Today, venom because of high selectivity and specificity towards protein subtypes and proteins, are valuable sources of anti-cancer drugs in fighting cancer for future. Presently, many peptide drugs isolated from venoms are existing in the marketplace for the treatment of diseases such as pain, multiple sclerosis, diabetes, cardiovascular disease and hypertension (Escoubas and King, 2009). Venom as a composition of various toxins is the most efficient cytotoxic agent available in nature. Toxic animals are widely existing in nature whether on land or sea(Escoubas and King, 2009). In the current study, we introduced new marine venomous animal in the southern waters of Iran (Persian Gulf) as a good source for anti-cancer drugs. All our results on U87MG human glioma cells and their mitochondria showed that crude venom of Conus textile has high selectivity and specificity at increasing cytotoxicity toward U87MG human glioma cells and their mitochondria compared to human embryonic kidney 293 cells. Therefore, Conus textile venom is a good promising agent for future anti-cancer research.

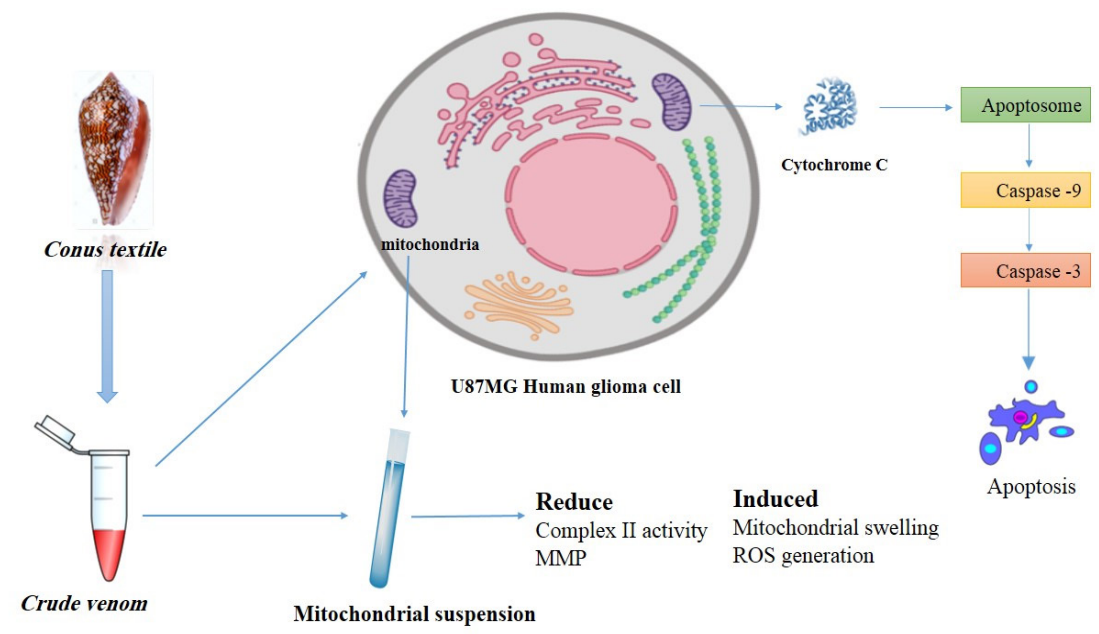

Figure 8. Graphical Abstract 
The programmed cell death or apoptosis, has a key role in cellular activities (Hengartner, 2000). Caspases as a family of protease in cytosol are the main and primary inducers of apoptosis within the cell. Cellular stress leads to activation of caspases like caspase 3, caspase 9, and caspase 12 and induce apoptosis (Fan et al., 2005). Our result in this study showed that crude venom of Conus textile selectively induces activation of caspase 3 through mitochondrial pathway only in U87MG human glioma cells. There are several animal toxins which induce apoptosis. Cellular stress induced by toxins leads to the disruption of cell organelles such as mitochondria and endoplasmic reticulum which results in the release of cytochrome c and glucose, calcium, which activates caspases (Ferreiro et al., 2008). It has been reported that several animal toxins target mitochondria in tumor cells. For example, cardiotoxin III isolated from the venom of snake Naja naja atra was shown to cause an anti-tumor effect through mitochondrial apoptotic pathway on human colorectal cancer cells (Tsai et al., 2006). It is evidenced that cardiotoxin III started the mitochondria-mediated apoptosis by an elevated $\mathrm{Bax} / \mathrm{Bcl}-2$ ratio, the release of cytochrome c, and activation of caspase 9. Up-regulation of pro-apoptotic markers such as inactivate nuclear factorkappa B (NF-kB), Bax and release of cytochrome $\mathrm{c}$ in breast cancer MCF-7 cells by cardiotoxin III were also reported. Our results in the current work showed that crude venom of Conus textile selectively targets mitochondria in U87MG human glioma cells and leads to mitochondrial swelling as a no return point and cytochrome c release. These results suggested that probably peptides like cardiotoxin III is available in crude venom of Conus textile.

Mitochondrial alterations such as mutations in mitochondrial genome along with somatic mutations in tricarboxylic acid cycle gene IDH, abnormalities in mitochondrial membrane potential, enhanced oxidative stress, shift to glycolysis from oxidative phosphorylation and apoptotic machinery are shown in gliomas (Guntuku et al., 2016). Targeting these alterations in human glioma cells could be very effective for treatment. Mitochondria are attractive pharmacological targets due to their key roles in ion homeostasis, regulation of redox signaling, induction of apoptotic cell death mechanisms and cellular metabolism (Ocloo and Dongdem, 2012). Peptides available in the venom of venomous animals such as Conus textile probably target mitochondria by either indirectly affecting metabolic alterations or directly binding to mitochondrial components. Inhibition of various electron transport chain complexes lead to enhancement of ROS formation, disbalance in cellular antioxidant system, targeting of ion channels and $\mathrm{Bcl} 2$ anti-apoptotic family proteins in the membrane of mitochondria which finally cause mitochondrial disruption and cell death induction (Liu et al., 2002; Orrenius, 2007). Our results in this study showed that crude venom of Conus textile selectively increased ROS formation in isolated mitochondria obtained from U87MG human glioma cells compared to isolated mitochondria obtained from human embryonic kidney 293 cells. These results suggested likelihood of presence of inhibitory agents of electron transport chain complexes in the crude venom of Conus textile.

Our results also showed which crude venom of Conus textile can be a promising source for anticancer drug candidates which selectively and directly target mitochondria in cancerous cells and could induce cell death through mitochondria-mediated apoptosis which finally ends in cytochrome c release, caspase 3 activation and apoptosis in U87MG human glioma cells. Our results provide promising tool in treatment of gliomas in in -vitro models by targeting mitochondrial specific effects probably by conotoxin available in Conus textile venom (Figure 8). However, such application of EA needs further investigation in animal and clinical trials.

\section{Acknowledgements}

The data provided in this article were extracted from the PharmD thesis of Dr Niloofar Rahimitabar. The thesis was conducted under supervision of Prof. Jalal Pourahmad at Department of Toxicology and Pharmacology, Faculty of Pharmacy, Shahid Beheshti University of Medical Sciences, Tehran, Iran. This work was supported by Shahid Beheshti University of Medical Sciences, Deputy of Research.

\section{Declaration of Conflicting Interests}

The authors declare that they have no conflict of interest.

\section{References}

Arab-Nozari M, Mohammadi E, Shokrzadeh M, et al (2020). Co-exposure to non-toxic levels of cadmium and fluoride induces hepatotoxicity in rats via triggering mitochondrial oxidative damage, apoptosis, and NF-kB pathways. Environ Sci Pollut Res, 1-11, In press.

Borhani S, Mozdarani H, Babalui S, et al (2017). In vitro radiosensitizing effects of temozolomide on U87MG cell lines of human glioblastoma multiforme. Iran J Med Sci, 42, 258.

Bradford MM (1976). A rapid and sensitive method for the quantitation of microgram quantities of protein utilizing the principle of protein-dye binding. Anal Biochem, 72, 248-54.

Bray F, Ferlay J, Soerjomataram I, et al (2018). Global cancer statistics 2018: GLOBOCAN estimates of incidence and mortality worldwide for 36 cancers in 185 countries. $C A$ Cancer J Clin, 68, 394-424.

Burz C, Berindan-Neagoe I, Balacescu O, et al (2009). Apoptosis in cancer: key molecular signaling pathways and therapy targets. Acta Oncol, 48, 811-21.

Chen N, Xu S, Zhang Y, et al (2018). Animal protein toxins: origins and therapeutic applications. Biophys Rep, 4, 233-42.

Dang L, Jin S, Su SM (2010). IDH mutations in glioma and acute myeloid leukemia. Trends Mol Med, 16, 387-97.

Davis ME (2016). Glioblastoma: overview of disease and treatment. Clin J Oncol Nurs, 20, S2.

Escoubas P, King GF (2009). Venomics as a drug discovery platform. Expert Rev Proteomics, 6, 221-4.

Faizi M, Salimi A, Rasoulzadeh M, et al (2014). Schizophrenia induces oxidative stress and cytochrome $\mathrm{C}$ release in isolated rat brain mitochondria: a possible pathway for induction of apoptosis and neurodegeneration. Iran J Pharm Res, 13, 93-100.

Fan T-J, Han L-H, Cong R-S, et al (2005). Caspase family 
proteases and apoptosis. Acta Biochim Biophys Sin, 37, 719-27.

Favreau P, Stöcklin R (2009). Marine snail venoms: use and trends in receptor and channel neuropharmacology. Curr Opin Pharmacol, 9, 594-601.

Ferreiro E, Oliveira CR, Pereira CM (2008). The release of calcium from the endoplasmic reticulum induced by amyloid-beta and prion peptides activates the mitochondrial apoptotic pathway. Neurobiol Dis, 30, 331-42.

Guntuku L, Naidu V, Yerra VG (2016). Mitochondrial dysfunction in gliomas: pharmacotherapeutic potential of natural compounds. Curr Neuropharmacol, 14, 567-83.

Harvey AL (2014). Toxins and drug discovery. Toxicon, 92, 193-200.

Hashim D, Boffetta P, La Vecchia C, et al (2016). The global decrease in cancer mortality: trends and disparities. Ann Oncol, 27, 926-33.

Hengartner MO (2000). The biochemistry of apoptosis. Nature, 407, 770 .

Kohn AJ (2016). Human injuries and fatalities due to venomous marine snails of the family Conidae. Int J Clin Pharm Th, 54, 524.

Lee C-W, Hsu L-F, Lee M-H, et al (2018). Extracts of Artocarpus communis induce mitochondria-associated apoptosis via pro-oxidative activity in human glioblastoma cells. Front Pharmacol, 9, 411.

Liu Y, Fiskum G, Schubert D (2002). Generation of reactive oxygen species by the mitochondrial electron transport chain. $J$ Neurochem, 80, 780-7.

Ma R, Mahadevappa R, Kwok HF (2017). Venom-based peptide therapy: Insights into anti-cancer mechanism. Oncotarget, 8, 100908.

Mir R, Karim S, Amjad Kamal M, et al (2016). Conotoxins: Structure, therapeutic potential and pharmacological applications. Curr Pharm Des, 22, 582-9.

Mirshafa A, Mohammadi H, Shokrzadeh M, et al (2020). Tropisetron protects against brain aging via attenuating oxidative stress, apoptosis and inflammation: The role of SIRT1 signaling. Life Sci, 248, 117452.

Ocloo A, Dongdem JT (2012). Mitochondria as pharmacological targets: The discovery of novel anti-obesity mitochondrial uncouplers from Africa's Medicinal Plants. Afr J Tradit Complem, 9, 256-.

Orrenius S (2007). Reactive oxygen species in mitochondriamediated cell death. Drug Metab Rev, 39, 443-55.

Prashanth JR, Hasaballah N, Vetter I (2017). Pharmacological screening technologies for venom peptide discovery. Neuropharmacology, 127, 4-19.

Salimi A, Roudkenar MH, Sadeghi L, et al (2016). Selective anticancer activity of acacetin against chronic lymphocytic leukemia using both in vivo and in vitro methods: key role of oxidative stress and cancerous mitochondria. Nutr Cancer, 68, 1404-16.

Sawyers C (2004). Targeted cancer therapy. Nature, 432, 294.

Tabaraki N, Shahbazzadeh D, Moradi AM, et al (2014). Analgesic effect of Persian Gulf Conus textile venom. Iran J Basic Med Sci, 17, 793.

Tayo LL, Lu B, Cruz LJ, et al (2010). Proteomic analysis provides insights on venom processing in Conus textile. J Proteome Res, 9, 2292-301.

Torre LA, Bray F, Siegel RL, et al (2015). Global cancer statistics, 2012. CA Cancer J Clin, 65, 87-108.

Tsai C-H, Yang S-H, Chien C-M, et al (2006). Mechanisms of cardiotoxin 1ll-induced apoptosis in human colorectal cancer colo205 cells. Clin Exp Pharmacol Physiol, 33, 177-82.

Zhu J, Zuo J, Xu Q, et al (2011). Isocitrate dehydrogenase mutations may be a protective mechanism in glioma patients.
Anticancer Potential of Crude Venom of Conus Textile

Med Hypotheses, 76, 602-3.

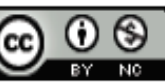

This work is licensed under a Creative Commons AttributionNon Commercial 4.0 International License. 